\title{
Death from smoking in the RJ Reynolds family
}

\author{
They died from smoking the family brands
}

Patrick Reynolds remembers his father, Rf Reynolds $7 r$; his aunt, Nancy Reynolds; his brother, Rf Reynolds III; and others in this personal memoir of the Reynolds tobacco family.

The phone call came as a surprise. It was the secretary of the elderly attorney in WinstonSalem, North Carolina, USA, who for several decades had represented my half-brother Josh, or Richard Joshua Reynolds III, as he sometimes preferred to be known. The woman, whom I did not know, was calling to let me know that Josh had passed away the day before, on 28 June 1994, at around 4 pm.

Although I knew Josh was deeply and irreversibly ill, I hadn't expected to lose him so soon. We had been close, and I had wanted to see him one last time to say goodbye. A deep sadness flooded over me as I hung up the 'phone.

It seems incredible but on that day I was still unaware that my half-brother died from emphysema, caused by his lifelong smoking of the RJR owned Camel and Winston brands. Josh had told me about a year before, "Patrick, I have a very serious heart condition. My doctors say I only have a year or so to live." He said nothing about having emphysema.

I had suspected that his cigarette addiction may have caused his heart disease but at that point I did not confirm it by calling his doctors.
Certainly I would not upset my eldest brother by asking him; one had better not even think such thoughts in his presence. So I put the idea into the far back of my mind.

\section{My half-brother, RJ Reynolds III}

The last time I saw Josh was in January 1994. It was on the occasion of the funeral services of Marie, his wife of 30 years. Also a longtime smoker, she had died of ovarian cancer. An old friend and ally of mine, she was the opposite of Josh-extroverted, with a wide range of friends, mostly from the "horse set" with inherited money. She was a well-known personality on the East coast horseshow circuit, and she trained and rode hunter-jumpers at their estate in Southern Pines, North Carolina.

I found Josh in deep mourning over Marie, gravely ill, hospitalised in intensive care. He was in the same hospital where Marie had just died, Good Samaritan in West Palm Beach, California. Josh was so ill that he was unable to attend his wife's funeral services. Instead he sent a video crew to the overflowing church, so that he could later view the proceedings.

My brother had an oxygen tube running from behind both ears under his nose; at times, he had to wear a full oxygen mask. He was only rarely able to speak or move; it was an ordeal for him even to lift a fork to his mouth. On good days Josh was able to walk 25 feet $(7.6 \mathrm{~m})$

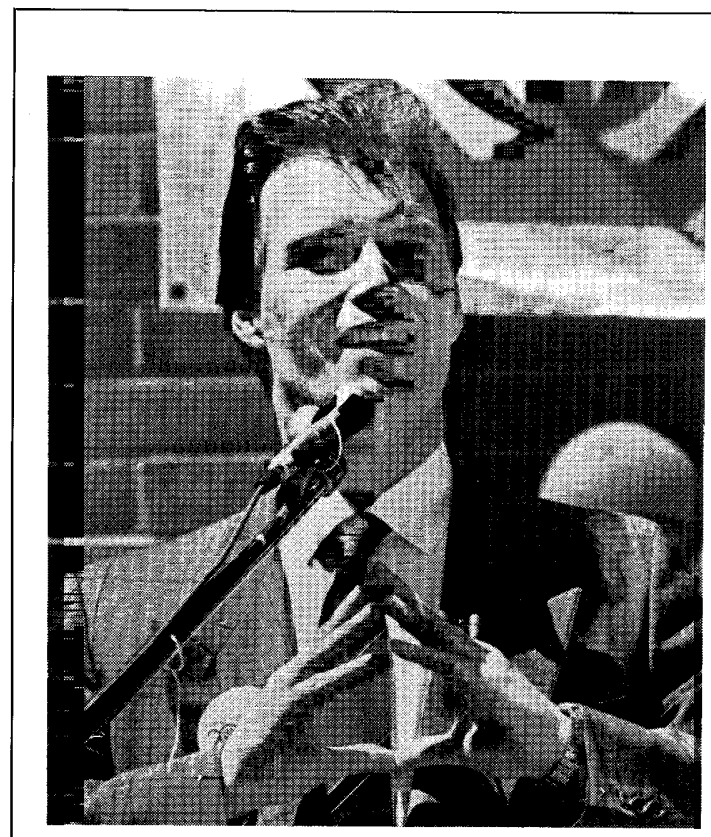

\section{About Patrick Reynolds}

A grandson of RJ Reynolds and a leading smoke-free advocate, Patrick Reynolds is a fulltime speaker before health conferences and universities. Media coverage of Reynolds' lectures and legislative testimony have brought his message about smoking and the need to regulate tobacco to millions of people. In the photograph shown on the left, Patrick is speaking to several hundred third- to sixthgrade students in Portland, Oregon in May 1988 (photograph by The Oregonian (Portland)). He may be contacted at the following address: Citizens for a Smokefree Society, 505 South Beverly Drive, Suite 1000, Beverly Hills, California 90212 USA; tel +1310 2771111 ; fax +13106571822 . 


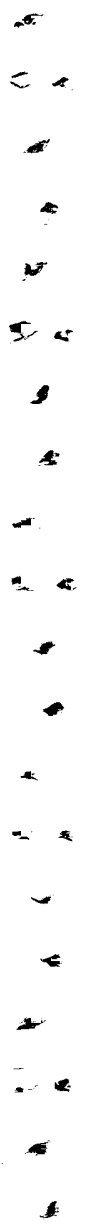

$+$

$+$,

$\times$

$\leftarrow$

$-$

$-$

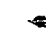

A

4

$+\quad$

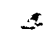
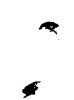

$2 \div$

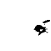

a.

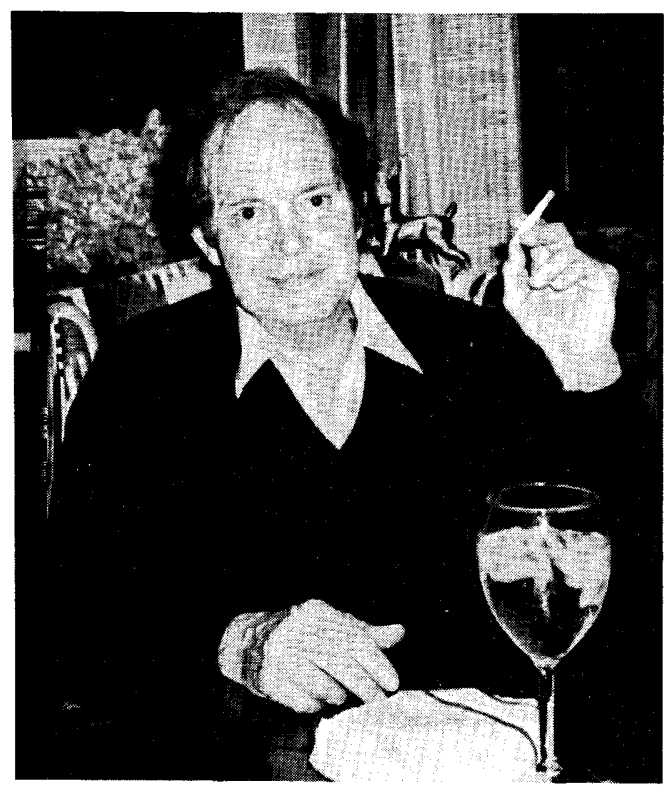

RF Reynolds III ( $\mathfrak{O}$ osh), Patrick's half-brother. RFR III smoked Camel and Winston cigarettes, and died from emphysema on 28 fune 1994.

down the hall. Instead of speaking, he wrote short notes for the stream of visitors from his wife's funeral services. The unending flow of well-wishers that week left him exhausted.

I extended my stay a week to be near Josh. Even though he couldn't speak, he conveyed a lot of love and caring to me. As I said goodbye on my last day with him, he managed to smile warmly and made a hand gesture indicating everything was okay.

But after that, he never answered my calls or letters, and would not send word to let me visit. He remained in intensive care for five months, moving in May to a hospital in Winston-Salem, and finally moving back to his thoroughbred farm in Southern Pines. He died less than a month after arriving home, only 60 years old.
Josh's refusal to communicate troubled me, and was a mystery to me. I remember that he always closely guarded his anonymity and sometimes had commented to me about his intense dread of publicity. Introverted and shy, he tended to be reclusive. Most of their friends were drawn to their home by his extraordinary and charismatic wife. Marie was playful, positive, and outgoing, and her invitations brought them a regular flow of houseguests and local friends. Although they had no children, they had four cats and six dogs - all strays they had found and adopted, except Marie's newest favourite, a miniature poodle. And of course there were seven magnificent horses down in the stables. Without Marie, I believe Josh would have lived out his life almost as a hermit, mostly alone and preferring to shut out the outside world.

Josh and I had never argued over my career in smoke-free advocacy. Years earlier, he had expressed some mild disagreement with my work but then had never mentioned his feelings again. As a friendly poke in the ribs, I would sometimes send him copies of the publicity attendant to one of my lectures; but I did this infrequently, as I did not wish to provoke him by sending a new round of clippings each month. My secret hope was that he would "see the light" and at least privately agree with me. He never did. At least he quit smoking in 1992, although we never spoke a word about it. Once he told me: "I'm glad to see you succeeding in your career, Patrick, because you're my brother. But I don't agree with what you're doing. Just keep me out of the press do you have any idea how many people already write me, asking for money? I hate it!" While he lived, I fully honoured his wishes, and protected his privacy. In The gilded leaf (Little Brown, 1989), the family biography I coauthored, I mentioned only the bare essentials about him, and he and Marie approved the text about them before the book's publication.

In general, Josh was very benevolent toward

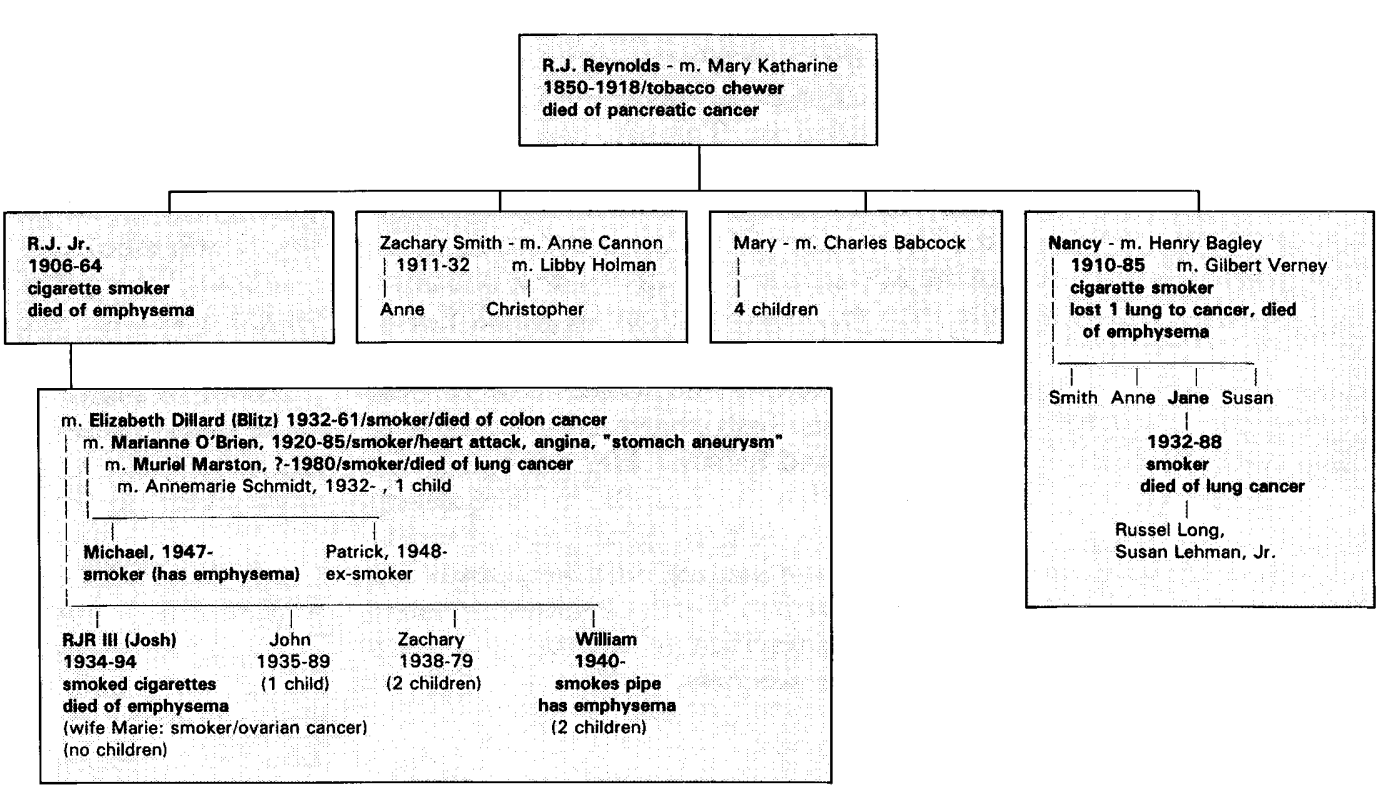


me, and we had a warm friendship. For the past 20 years or so, I had visited him and Marie about twice a year, often at Christmas or the New Year. So his behaviour at the end of his life puzzled me.

Why did he cut off communication with me? Thanks to the news clippings I occasionally sent, he was very aware that I'm a frequent speaker on tobacco control before health conferences and universities. Perhaps my brother was fearful of a media circus if someone leaked to reporters that RJ Reynolds was dying from smoking. The truth is I would never have subjected him to that while he lived. Evidently he didn't trust me, or very many others for that matter.

In addition, Josh's refusal to let me visit during his last six months may also have been brought on by his considerable pride - and deep shame and anger-about the products that were killing him. He never did admit to me that he had emphysema, or that smoking was the cause of his illness.

\section{$\star \star \star$}

In May, a family member told me which Winston-Salem hospital he was in, but when I called the hospital, the operator said she was "not permitted to give out any information as to whether he was a patient there", and that there was "no listing for that name". Then she forwarded my call to the hospital's security department. Two more calls brought the same result. It was obvious that Josh was only allowing certain visitors to get through. This anguished me, because I thought we had been very close. A few other family members I spoke to felt shut out as well.

Clearly he was very ill; it could be he simply didn't want to see anyone except his two best friends, Tommy Walters and Burr Collier, who stayed in his hospital room in 12-hour shifts. Josh did not even spend much time with his wife in her last months, even though they lay dying in the same Palm Beach hospital.

"I don't want him to see me like this," she said; and I think he felt the same way. A brief and final exception to this came in late 1993. Marie, attended by Tommy, had for several months been trying alternative therapy cancer clinics - first a costly experimental programme at the University of California at Los Angeles, then in Mexico, and finally in the Bahamas, while Josh remained at home in North Carolina. But when he got word that her most recent cure wasn't working, no longer able to bear their separation, Josh chartered a Lear jet to visit her in Grand Bahama. He then had the jet bring them both to the hospital in Palm Beach, where he too checked in. After years of saving on gas bills by not heating the cavernous living room at their farm in North Carolina, and after years of being terrified to fly, he must have known the end was near.

\section{Aunt Nancy}

The past was repeating itself. Our father's sister, Nancy Reynolds Bagley Verney, also a child of founding patriarch RJ Reynolds, died from smoking in early 1985. Aunt Nancy had had one lung removed due to lung cancer, and died from emphysema in the other lung. The story completely escaped notice by the press (as it would have with Josh had I not brought it to their attention). Shortly before her death, Town and Country magazine named her as one of the 10 most generous living Americans.

I remember the last time I saw her. It was in the summer of 1984. I used to take the train up to Greenwich, Connecticut during stops in New York to spend the day visiting her; usually she would drive to the station herself to pick me up. She had a large estate in Bel Haven, Quarry Farm. Diana Ross had bought her enormous mansion on the sprawling grounds, and Aunt Nancy had remodelled the former gardener's home a quarter of a mile $(400 \mathrm{~m})$ away on the property and moved into it.

She didn't meet my train this time but instead sent her secretary. When I saw her, I noticed she had an oxygen bottle in tow, but of course I avoided calling attention to it. In the past, she had loved to take me on speedy golf cart rides down paths around her wooded grounds; she loved to pause and point out the different wild flowers by name. She was an avid devotee of the relatively new science of ecology, whose first studies had been funded by my father in the late $1950 \mathrm{~s}$. The famous study "The ecology of a salt marsh" was credited with spearheading the modern ecology movement; it was conducted on his favourite estate, Sapelo Island, off the Georgia coast.

Today there would be no golf cart ride. Diana Ross, who was out for a walk with a friend, dropped by unexpectedly, and we all had an amiable chat. After they left, Aunt Nancy felt like going out for lunch. As we slowly ascended the few steps to the front door of the Greenwich Yacht Club, I remember what an ordeal every step was for her. After each step, she stopped, out of breath, and uttered a loud, guttural moan, as though attempting to clear her lungs. After that, she had to rest almost a minute before taking the next step. Finally we made it inside.

By then, she had quit smoking but I was still a smoker. As I dragged on a Winston after lunch, she asked me, "When do you think you'll quit smoking, Patrick?"

"Soon," I replied. "It's a pretty tough one for me. I've tried so many times." She nodded sympathetically and then changed the subject.

About six months later, in January 1985, she passed away; I quit smoking myself in March, and first spoke out against smoking the following year, in July of 1986.

\section{My father, RJ Reynolds Jr}

RJ Reynolds Jr, my father, died of emphysema in December of 1964. Evidently no journalist thought of it as a news story or investigated matters beyond the usual biographical obituaries for a man of his stature. Naturally, no family member called attention to the actual cause of death.

My father began smoking Camels as a

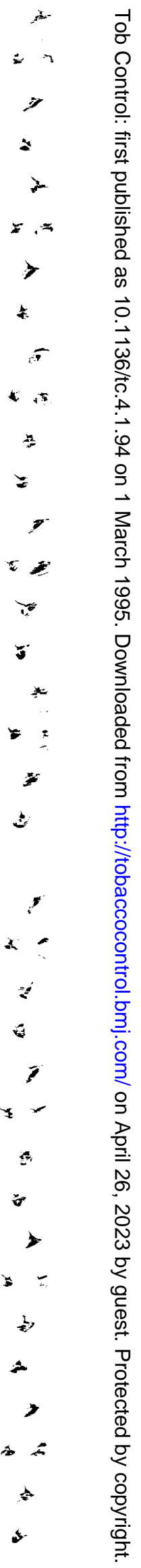




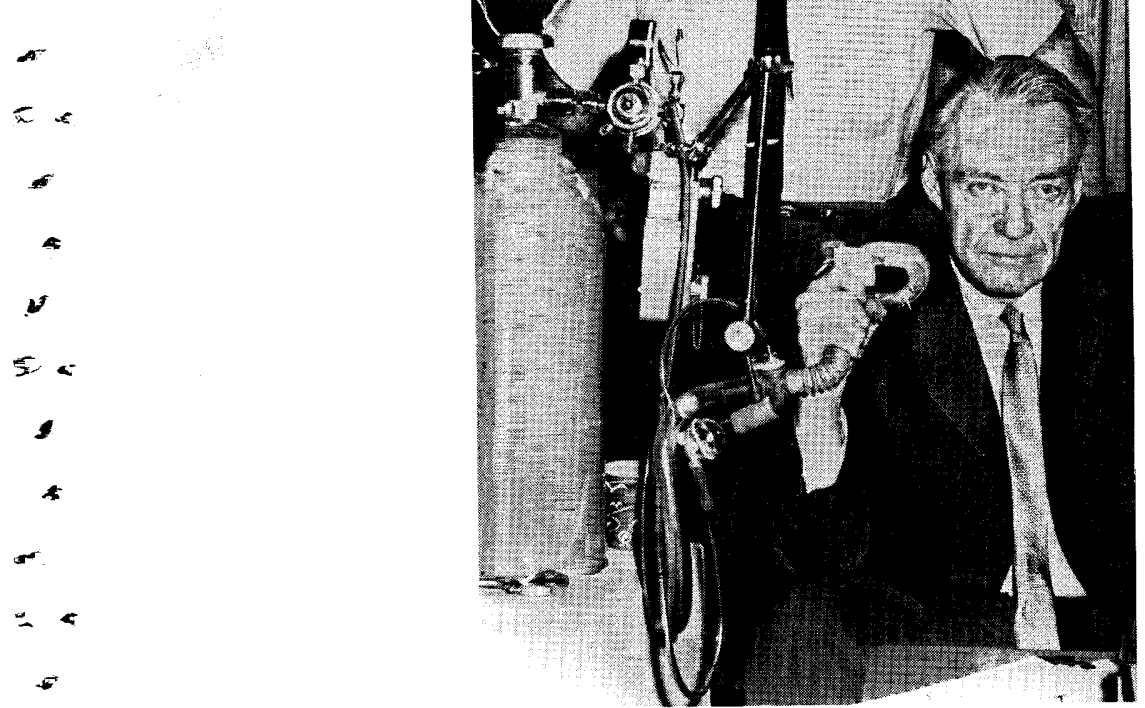

Rf Reynolds $\mathcal{F r}$ (Patrick's father), holding his oxygen apparatus in 1962. RfR $\mathcal{F r}$ smoked Camels and Winstons, and died from emphysema on 16 December 1964. (Source: Bettman Archives)

teenager in the 1920s. Tobacco and alcohol went hand in hand for the gilded youth of the age of F Scott Fitzgerald. By day, he financed Broadway shows from his overly generous $\$ 50000$ per year allowance and obsessively flew the latest biplanes; and by night, he squired showgirls into posh "speak-easies", where he hung out with the notables of New York's café society. Having a Camel in his hand came as naturally as drinking gin and tonics; and besides, wasn't that what people expected of RJ Reynolds Jr?

But he didn't do what some back home in North Carolina expected of him. He only worked briefly at the RJ Reynolds Tobacco Company as a boy, on the factory floor at a cigarette machine. In those days, around 1918, $\mathrm{RJ} \mathrm{Jr}$ was under the supervision of RJ's younger brother, Uncle Will, who did his best to rear the unruly young heirs after RJ passed on. Later, in the 1940s, after much resistance from those running the company, RJ Jr would serve on RJR's Board of Directors for a short period. After that he resumed his career of yacht racing, politics, and financing airlines. Probably due to his youthful fascination with flying, he was, in succession, the principal financier and stockholder of Piedmont, Eastern, and Delta airlines.

The death of his younger brother Smith in 1932 brought my father's playboy period to an abrupt halt. Within two months after returning home for Smith's funeral, RJ Jr married. He got word of Smith's death while chained to a tree on the African coastline; this was his way of detoxifying after a drinking binge during a trip on a tramp freighter he'd converted to a yacht. He entered Democratic politics, and was easily elected Mayor of Winston-Salem. Later he was appointed treasurer of the Democratic Party, and made contributions credited with electing two Presidents - Franklin Delano Roosevelt and Harry Truman. Toward the end of his life, he turned his attention to philanthropy.
No descendants of RJ Reynolds devoted their career to working in the company. Only Aunt Nancy's son Smith Bagley worked there for a time but he did not rise to a top position, and soon left. Just one second cousin has worked for the company.

The explanation for this is simple: founder RJ was so busy building his empire in the late 1800 s that he neglected to marry until 1905, at age 55 . His late marriage had the consequence that he failed to mentor, teach, and guide his children into the family business. He died at 67 (of pancreatic cancer), when his eldest child, my father, was only 12 . Left with a huge allowance and a $\$ 28$ million inheritance which he received at $28, \mathrm{RJ} \mathrm{Jr}$, as a youth, had little motivation to work; nor did younger siblings Smith, Mary, or Nancy.

The elder RJ did take pleasure, however, in mentoring and teaching his nephew, Richard Samuel (RS) Reynolds, who was old enough at the time to benefit. RS left the company when RJ's first son was born, and then went directly on to found Reynolds Aluminum.

$$
\star \star \star
$$

My mother, second of my father's four wives, loved to tell the story of how she took up smoking in 1944. She thought it would please my father, but when RJ Jr first saw her smoking, he said, "That's a dirty, filthy, disgusting habit. Put that cigarette out right now!' But she was addicted and continued to smoke, as did my father. In the late 1960s and during the 1970 s, she would urge me to quit smoking but I continued until 1985.

By 1960 RJ Jr had been diagnosed with emphysema. He promised his last wife, Annemarie, that he would quit. At the time he was living on his magnificent 36-square-mile (93$\mathrm{km}^{2}$ ) private island estate, Sapelo, off the Georgia coast, today an ecological preserve owned by the State. When Annemarie discovered that he was bribing a "loyal" servant to slip him cigarettes, she summarily fired the entire household staff of over two decades.

Like his son Josh, during his last six months our father spurned all visitors and contact with the outside world. He even refused to see his own sons. His son John, who travelled to the village in Switzerland where $\mathrm{RJ} \mathrm{Jr}$ died, was turned away at his door. The other sons had no address or telephone number for him, except an office number in London. When Father died, I was newly 16, the youngest of his six sons. I hardly knew him, as I was only able to visit him on five occasions, between the ages of nine and 12. The day after RJ Jr died, his only daughter, Irene, was born to Annemarie in Switzerland.

$$
\star \star \star
$$

Tragically and ironically, the Reynolds family history is full of smoking-caused deaths. To summarise, my grandfather, founding patriarch RJ Reynolds, had four children, all of whom smoked. Of these, two definitely died from smoking - first, RJ Jr, and then Nancy. A 


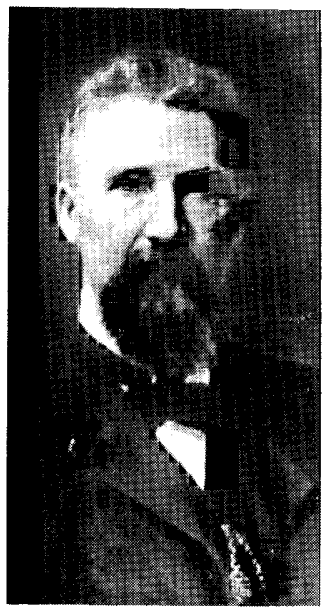

Rf Reynolds (Patrick's grandfather), who founded the tobacco company in 1875, which began manufacturing Camel cigarettes in 1913. A tobacco chewer, the patriarch of the family died in 1918 at the age of 67, from pancreatic cancer. third, Mary, died of stomach cancer in her $40 \mathrm{~s}$, which may have been linked to her cigarette smoking. ${ }^{\star}$ (The fourth, Smith, died at 21 in a sensational scandal of the early 1930s: Smith's older wife, torch singer Libby Holman, whom he met while carousing with my father in New York, was indicted for his murder but was later acquitted. It was never proved whether Smith's death was a murder or suicide.)

So half of RJ Reynolds' children definitely died from the product that he was instrumental in popularising. And the patriarch himself died in 1918 at 67 , from cancer of the pancreas, which may have been caused by his addiction to chewing tobacco. Ironically, this was the product that made his parents and grandparents into prosperous, landed farmers, and "plug" was the foundation on which RJ's own empire was initially built.

\section{$\star \star \star$}

Of my father's four wives, the first three smoked. The first, Blitz, who was from an aristocratic Winston-Salem family, died in 1961, at age 52, of colon cancer; her death may have been smoking-related. $f$ They had four sons; the eldest was Josh. My father's second wife, Marianne, who was my mother, was a beautiful movie starlet under contract to Warner Brothers in the 1940s. She had two sons (Michael is my full brother). She too smoked, which probably hastened her death; she had a heart attack in the mid-1970s, followed by angina, and died in 1985 from a "stomach aneurysm". $¥ M y$ father's third wife, Muriel, had no children, and died from smoking-caused lung cancer in 1980. Annemarie, his fourth wife and widow, never smoked and is in good health. She and my sister Irene live in Switzerland.

In the third generation, my eldest brother Josh's death was caused by smoking. Josh's full brother Will, a pipe smoker living in Winston-Salem, now has emphysema. My brother Mike still smokes and has beginning

‡ There is some evidence that smoking may cause gastric cancer. See, for example, Kneller RW, et al. Cigarette smoking and other risk factors for progression of precancerous stomach lesions. $\mathcal{f}$ Natl Cancer Inst 1992; 84: 1261-6. - ED

$\dagger$ Two recent articles reported an association between smoking and colorectal cancer: (a) Giovannucci E, Rimm EB, Stampfer MJ, et al. A prospective study of cigarette smoking and risk of colorectal adenoma and colorectal cancer in US men. $\mathcal{F}$ Natl Cancer Inst 1994; 86: 183-91; and (b) Giovannucci E, Colditz GA, Stampfer MJ, et al. A prospective study of cigarette smoking and risk of colorectal adenoma and colorectal cancer in US women. $\mathcal{F}$ Natl Cancer Inst 1994; 86: 192-9. - ED

$¥$ Smoking is, of course, a well-known cause of cardiovascular disease, including myocardial infarction (heart attack) and angina pectoris. "Stomach aneurysm" here may refer to abdominal aortic aneurysm, the rate of mortality from which is $2-8$ times higher in current smokers than in never-smokers (see pages 192-5 of the 1983 Surgeon General's report and pages 241-2 of the 1990 Surgeon General's report). - ED

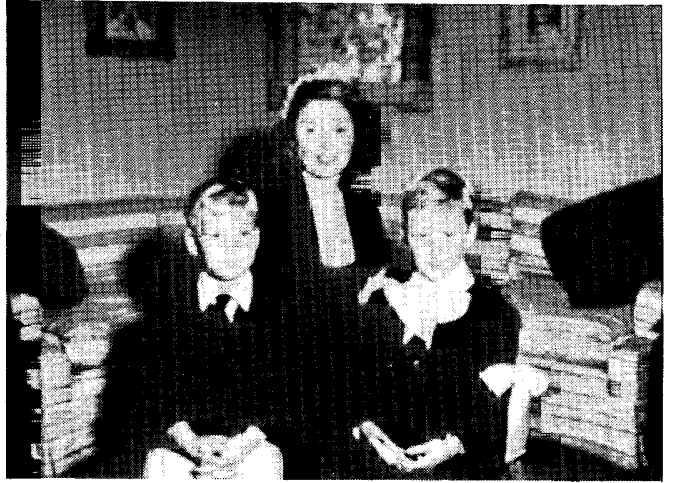

$R f R$ Ir's second wife, Marianne (after their divorce), poses with her sons Patrick (left) and Michael (right), on the occasion of Michael's first communion. Marianne, a smoker, died in 1985 at the age of 40 from a "stomach aneurysm" after years of heart disease.

emphysema. Josh's wife Marie smoked, and died from ovarian cancer.

Aunt Nancy's daughter, Jane, died in 1988 from lung cancer caused by her cigarette addiction. (I was unable to obtain information on the descendants of my Uncle Smith.)

As this chronology has shown, smoking has decimated the RJ Reynolds family.

$$
\star \star \star
$$

Today cigarettes are causing about one of every five deaths in the US. I'm convinced that the Reynoldses are far from the only family with an unspoken protocol at funerals of avoiding mention that tobacco addiction caused the beloved one's death. Even obituaries for the famous often omit this. Talking about it is seen as somehow disrespectful, shaming the memory of the deceased, and prodding an already open family wound. The overwhelming fact of the loss towers in importance over whatever its cause may have been. Give the dead their peace, and let the living heal. All of this goes without saying. I heartily applaud the new laws passed by some states which require doctors to note on death certificates if smoking caused the death.

$$
\star \star \star
$$

When I flew to Palm Beach in early July for Josh's burial services, no one mentioned that he had died from smoking, and no one alerted the press. So, as with Aunt Nancy, and as with our father's passing from emphysema, the fact that cigarettes caused RJ Reynolds III's death would have gone completely unnoticed. It would have continued what was already a family tradition.

In the days following Josh's death, still grieving, I considered whether to make the story public. Who among our family, I wondered to myself, would be offended? Newly widowed, Josh had no children, and his mother and grandparents had died many years earlier. Probably his and Marie's friends from the horse circuit would not mind so much.

Only his two best friends, Tommy Walters 


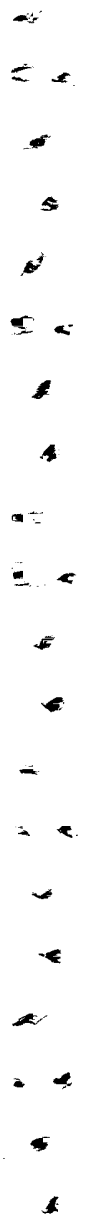

$2=$

$\leftarrow$

5

$-$

$\checkmark$

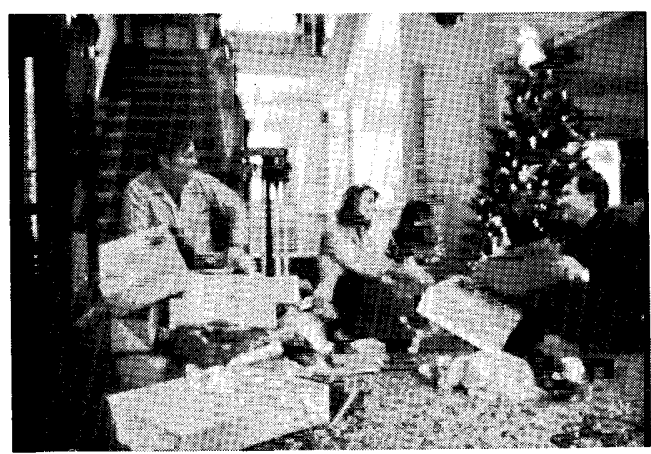

Patrick, visiting his brother Michael (left) at Christmas in North Carolina, and Michael's wife (Gail) and stepdaughter (Bonnie). Michael, a smoker, has early-stage emphysema.

and Burr Collier, might be disturbed. They had tended Josh day and night for six months; and before that, they looked after Marie for a full year. Josh's brother Will might care, but then Will had not been close to any of his brothers in recent years.

Neither Josh nor I had ever been close to our tobacco cousins, who didn't much care for the multigenerational family history I co-authored in The gilded leaf.

I knew that my full sibling, Mike, to whom I am even closer than I was to Josh, would fully support my telling the press that our eldest brother had died from smoking-caused emphysema. Mike, a lifelong smoker, now has emphysema at an early stage himself. But I believe that nagging loved ones backfires and keeps them smoking, and so I briefly mention it to him only on occasion.

All of this considered, I made the decision to take the story public. I reached Josh's doctor at Good Samaritan Hospital in Palm Beach. He confirmed that Josh had died of end-stage emphysema, caused by smoking. With his permission I listed his name and telephone number on the press release, so reporters could contact him directly. Interestingly, Josh's doctor at the Winston-Salem hospital would not comment, but told me, "I'm under constraints here. I hope you understand".

When I finally made the announcement on 12 June, two weeks after Josh's death, the story was carried in major print and broadcast media around the world. The journalist from the New York Times was incredulous. "How could this go unnoticed for two weeks?," he asked. "Why didn't we get the news right away?" I explained that I wanted time to think and grieve, and hadn't wanted television crews climbing around during my brother's funeral.

For the first time, the role of smoking in causing the death of an RJ Reynolds family member became public knowledge around the time of death. It was high time.

$$
\star \star \star
$$

In his will, Josh left everything, about $\$ 10$ million, to a new foundation in WinstonSalem, the Josh and Marie Reynolds Foundation. He left nothing to any of his family and only token amounts to his closest friends and long-time servants. Sadly, he may have felt like he hadn't accomplished much during his life; his primary pursuits had been reading, especially the work of alternative thinkers who delved into the metaphysical and psychic realms. He also wrote some wonderful poetry, which he published himself near the end of his life.

Creating this new foundation was very important to Josh; my hope is that it will do a great deal of good. Unfortunately it will be run largely by his executor, the venerable WinstonSalem attorney Norwood Robinson, and his son Mike. My guess is that they will not look too kindly on tobacco control grant applications, even though the foundation is empowered to make grants to any cause the board decides on. Some in Winston-Salem, or "Cigarette City" as the locals sometimes call it, are not at all supportive of our work. Ah, well....

$$
\star \star \star
$$

My father left his children minimal amounts of money because he wanted us to work. Most of Josh's estate came from his wealthy mother, Blitz. RJ Jr never imagined that as a grown man I'd go against the family business - but I'm sure that these days he and grandfather RJ are strongly rooting for me from on high. They never knew the full extent of the harm that would be caused by the products made by RJ Reynolds Tobacco.

$$
\star \star \star
$$

According to one recent study, of the two billion smokers now in the developing world, fully 200 million are expected to die from smoking. I'm now looking for major donors to fund my group in Los Angeles, Citizens for a Smokefree Society, to allow me to go on a speaking tour of one or more developing countries. If I do, I hope media coverage of the tour will bring the message about smoking to hundreds of millions of people. I love this work, I'm dedicated to it, and will continue fighting tobacco use for the rest of my life. 